opposed effects of long days according to whether the temperature is or is not high enough for rapid bulbing. To this opposition may be attributed much of the apparently erratic bolting of onions grown from sets in various seasons and localities. The suppression of bolting by high temperatures in the absence of bulbing is unlikely to be of importance in Great Britain, as temperatures are seldom high enough except in the long summer days such as favour bulb formation.

It must be emphasized that the above experiments were performed with sets, and the plants had therefore been exposed to long days in the previous year during their production from seed. A further experiment starting with seeds may therefore be cited, in which the day-length was maintained throughout at less than twelve hours. These plants formed no bulbs, but produced inflorescences after some eighteen months. Clearly, therefore, at no stage during ontogeny are long days essential either for initiation or emergence of inflorescences, unless indeed the particular variety of onion used for this experiment was characterized by an exceedingly low photoperiodic requirement for flowering.

The experiments here discussed and further work now in progress will be published in full in due course.

${ }^{1}$ Mcclelland, T. B., J. Agric. Res., 37, 603 (1928).

${ }^{2}$ Magruder, R., and Allard, H. A., J. Agric. Res., 54, 719 (1937).

${ }^{3}$ Thompson, H. C., and Smith, O., Cornell Univ. Agric. Exp. Sta.,

- Heath, O. v. S., (Pt. 1), Ann. Appl. Biol. (in the press)

5 Heath, O. V. S., (Pt. 2), Ann. Appl. Biol. (in the press).

- Purvis, O. N., Ann. Bot., 48, 919 (1934).

' Sideris, C. P., Amer. J. Bot., 12, 255 (1925).

\section{RESEARCH ON EARLY MAN IN BURMA}

$\mathrm{O}^{\mathrm{F}}$ recent years it has become increasingly evident that so early as lower palæolithic times human culture was not the same all over the world, and that the dissimilarities probably resulted from differences in race. Even in such a small area as the continent of Europe, it is clear from a study of distribution maps of stone age cultures that in Central and Eastern Europe the stone industries differ entirely from those found in the west, and furthermore the two groups undergo quite different developments. Whereas central and eastern Europe can obviously be linked with northern Asia, the stone industries of western Europe show close affinities with the lower palæolithic finds of the African continent. Although skeletal remains of this early date are extremely rare, the few sure indications that have turned up also seem to point to the same connexions. Now a third region has been entered and we find there a series of industries closely allied with others from south-east Asia, but dissimilar to their contemporaries in northern Asia or in Africa.

The Transactions of the American Philosophical Society (32) includes a scholarly account of the work undertaken, which was (1) to study the pleistocene period in Burma and to establish a chronological sequence for the alluvial formations of the Irrawaddy Valley, and (2) to investigate any stone age industries discovered in the course of the above researches. Hellmut de Terra, well known for his similar work in northern India, was responsible for (1), Hallam $\mathrm{L}$. Movius, jun., for (2). Supplementary reports on the pleistocene vertebrates and molluses of the region are given by Edwin $\mathrm{H}$. Colbert and J. Bequaert respectively. There is also a note on an investigation undertaken by. de Terra in Java. The geological chapters include studies of the Irrawaddy basin and in the northern Shan Highlands, as well as comparisons with neighbouring areas in India, China and Malaya. Movius describes a series of industries (Anyathian) which appear in early mid-pleistocene deposits. They resemble the Soan complex of northern India, as well as industries found at a number of sites in Java. The Soan always has been considered to have been intrusive in northern India; it would now appear to have been an outlier from Burma. Movius also notes the similarity between the Anyathian and certain heavy industries from Choukoutien, but the typical smaller industries from this area have not been found either in Burma or in Java. The later Anyathian (late pleistocene) though showing certain so-called upper palæolithic peculiarities, is essentially an evolution of the earlier Anyathian, and this is clearly shown from a study of the development of a series of specialized tools made from an unusual material, fossil wood. An interesting collection of neolithic implements and pottery was also made and studied. The first two appendixes are mainly catalogues of the pleistocene vertebrates and freshwater shells found. But de Terra's note on his visit to Java raises again the vexed question of the date of Pithecanthropus erectus and that of the newly discovered human remains at Modjokerto. The latter apparently must be considered to be earlier in age than Dubois' find.

In this short note it is impossible to give any detailed account of these investigations. The authors have opened up a new field of study, both in the realm of quaternary geology and of prehistory. Obviously, an enormous amount remains to be done, but the foundations are here for the first time well and truly laid. M. C. BurkitT.

\section{A GIANT CAMERA}

A $\mathrm{N}$ article by Richard Haard (Bell Lab. Rec., 21, A No. 10; June 1943) describes the largest camera of its kind in the United States, this boing installed in the Photocopy Department of the Bell Laboratories, making so many as eight hundred negatives a day. It was made by the Rutherford Camera Co. and has one of the largest lenses of its kind in the country - a Goertz apochromat with a 72-in. focal length. The camera also has three other smaller lenses, and all four are interchangeable. With this camera a negative $3 \frac{1}{2} \mathrm{ft} . \times 6 \mathrm{ft}$. may be made as easily and quickly as one 8 in. $\times 10$ in. The photographer works inside the camera, in complete darkness except for a dim red light.

The new camera consists of two rooms with the lenses mounted in a sliding panel in the separating wall. One is a dark room that has a giant "plate holder", called the "camera back", running on a track on the floor that extends through the wall carrying the lens, and into the "light" room. In this latter room, the easel that holds the tracing to be copied runs on a carriage on the same track. The easel is of the vacuum type. The flanged edges of the glass cover fit against rubber gaskets when the cover is lowered, and the vacuum which is then applied holds the drawing flat against the glass face of the easel so that all curves will be accurately reproduced. After this the easel, which is pivoted at the front edge of the carriage on which it rests, is tipped up 
into a vertical position. It is equipped with piston devices that check its motion at the end of the swings so that tilting it up or turning it back is a simple and rapid procedure. Because of the height of the top of the easel carriage, which is half the length of the easel above the track, a bench $2 \mathrm{ft}$. high runs the entire length of the track to enable the operator to place the tracings on the easel. Two powerful arc lights on each side of the track near the lens provide illumination.

The "camera back" in the dark room is arranged for two widely different sizes of negatives. The vertical plate against which the paper is placed is perforated with fine holes, and a vacuum acting through them holds the paper flat. If the negative to be made is smaller than the perforated back, rubberized eurtains are drawn from the top and bottom and from the two sides to block off all holes except those covered by the paper. Vertical bars control the two side curtains.

Four men form the normal operating crew of the camera. In the light room, a man at one of the work benches measures the drawing, and from the size of the print called for, calculates which of the four lenses should be used. Using a loud-speaking telephone system interconnecting the dark and light rooms, he tells the operator in the dark room the results of his calculation. Four horizontal scales run the length of the tracks in both rooms and are used in setting the positions of both easel and "camera back" in accordance with the size of the drawing and the amount of reduction required. One scale is marked for each lens. After the operator in the dark room has mounted the proper size paper on the "camera back" and selected the proper lens, he moves the "back" to the designated marking on the scale for that lens. In the meantime, another operator in the light room has placed the tracing in the easel, tilted the easel up, and moved the carriage to the scale mark given him by the operator who has sized the drawing.

After the dark-room operator has finished his operation, he looks through a small red glass window in the wall to the right of the lens, and as soon as he sees the easel is in place, he operates a switch that turns on the arc lights. He then rotates a filter into position in front of the lens to cut down all but a negligible amount of light, uncovers the lens, and looks at the faint image of the tracing on the sensitized paper. Using hand wheels at one side of the "camera back", he then shifts the vertical and horizontal position of the lens so as to centre the image on the paper. Following this, he removes the deep filter, or replaces it with one that will best bring out the lines on the drawings, and makes the exposure. He stops the exposure by turning off the are lights, which also acts as a signal to the operator to place the next tracing in the easel.

The dark-room operator then removes his exposed paper and slides it through a chute to the adjacent developing room, where it is developed, washed, and fixed, and then placed on a glass-top under-lighted table for inspection. Any weak spots are brushed with ferricyanide so that they will print stronger. The negative is then passed through another chute to the washing tanks in the outer room. After the washing period, the prints are dried on the powerdriven drier and then passed through the oiling machine. This spreads a thin film of oil on the back to make the paper more transparent, and thus to decrease the printing time. Any excess oil is then wiped off and the negative is ready for printing.

\section{FORTHCOMING EVENTS}

\author{
Saturday, September 18
}

BRITISH RHrologists' CLUB (at Loughborough College, Loughborough), at 10 a.m.-Discussion on "Rheology in the Hosiery, Leather, Shoe and Allied Trades".

Association For ScInntific PHotography (at the Middlesex Hospital, London, W.1), at 2.30 p.m.--Discussion on "Clinical Photography".

\section{Saturday, September 18-Sunday, September 19}

Association of SPECIAL LIBRARIES AND INFORMATION BUREAUX (at the Royal Society, Burlington House, Piccadilly, London, W.1).-Eighteenth ASLIB Conference.

Saturday, September 18

10.30 a.m.-Annual General Meeting.

11.30 a.m.-Prof. J. D. Bernal, F.R.S.: "Positive Information Service".

2.0 p.m. - Symposium on "The International Rehabilitation of Special Library Services".

Sunday, September 19

10.30 a.m.-Mr. F. C. Francis: "The British Museum as a Special Library".

11.45 a.m.-Major Irving Newman : "The Organisation of American Photographic Information Services in Great Britain".

2.30 p.m. - Symposium on "The Co-ordination of Abstracting".

5.0 p.m.- "ASLIB : What it is Doing and What it Hopes to Do".

Wednesday, September 22

Instrete of Metals (at 4 Grosvenor Gardens, London, S.W.1), at 3 p.m.-Thirty-fifth Annual Autumn Meeting.

\section{Friday, September 24}

FARAday Society (at the Hotel Rembrandt, South Kensington, London, S.W.7), at 10 a.m.-A General Discussion on "Modes of Drug Action""

\section{Saturday, September 25}

British Psyohologrcal Society (at Tavistock House, Tavistock Square, London, W.C.1), at 2.30 p.m.-" "Education of the Adolescent".

\section{APPOINTMENTS VACANT}

APPLICATIONS are invited for the following appointments on or before the dates mentioned :

SENIOR Lecturer IN Electrical EngINeering-The Principal and Clerk to the Governing Body, Wigan and District Mining and Technical College, Wigan (September 23).

PHYSICIST TO THE RAdiotherapy Department-The Secretary, University College Hospital, Gower Street, Iondon, W.C.1 (September 27).

City Erectrical Fnginger and City Tighting Engineer-The Town Clerk, Municipal Buildings, Liverpool 2 (endorsed 'City Electrical Engineer and City Lighting Engineer') (September 30)

Aneer and City Lighting Engineer') (September 30 ). The Registrar, The University, Leeds (September 30).

CHAIR of SoctaL MEDICINE-The Secretary, The University, CHAIR OF SOCIAL MEDICINE The Secre
Edmund Street, Birmingham 3 (March 1).

UNIVERSTTY LECTURER IN ANTHROPOLOGY - The Secretary of the UNIVERSTTY LECTURER IN ANTHROPOLOGY -The Secretary of the
Appointments Committee of the Faculty of Archæology and Anthropology, Museum of Archæology and of Ethnology, Cambridge (April 15).

\section{REPORTS and other PUBLICATIONS}

$$
\text { (not included in the monthly Books Supplement) }
$$

Great Britain and Ireland

Ministry of Health. Third Report of the Central Advisory Water Committee : River Boards. (Cmd. 6465.) Pp. 73. (London: H.M. Stationery Office.) 1s. 3d. net. [198 Royal College of Physicians of Edinburgh. Annual Report by the Curator of the Laboratory for the Year 1942. Pp. 16. (Edinburgh : Royal College of Physicians of Edinburgh.) [ 248 Plan for Clean Air. Pp. 8. (Epsom: National Smoke Abatement Freshwater Biological Association of the British Empire. Eleventh Annual Report for the Year ending 31st March 1943. Pp. 40. Ambleside : Freshwater Biological Association of the British Empire.) 18. $6 d$.
[268 Other Countries U.S. Office of Education: Federal Security Agency. Bulletin, 1941,
No. 5: Bibliography of Research Studies in Education, 1939-1940. No. 5: Bibliography of Research Studies in Education, 1939-1940.
Prepared by Ruth A. Gray. Pp. xiv +404. (Washington, D.C.: Prepared by Ruth A. Gray. Pp. xiv +404. (Washington, D.C.
Government Printing Office.) 50 cents. Proceedings of the Academy of Natural Sciences of Philadelphia. vol. 92, 1940. Pp. iii +376 . (Philadelphia: Academy of Natural Vol. 92, 1940. Pp. iii +376. (Philadelphia: Academy of Natural
Sciences.) 7.50 dollars. Bulletin of the American Museum of Natural History. Vol. 81 Art. 3: Dentitional Phenomena in Cobras and other Elapids, with Art. 3 : Dentitional Phenomena in Cobras and other Elapids, with
Notes on Adaptive Modiflcations of Fangs. By Charles Mitchill Bogert. Notes on Adaptive Modiflcations of Fangs. By Charles Mitchill Bogert.
Pp. 285-360 + plates 48-51. (New York: American Museum of NatPp. 285-360+plates 48-51. (New York: American Museum of Nat-
ural History.) 